may be reckoned the so-called 'Lusitanian' flora, species which occur in south-western Ireland or in south-west England and also in the Iberian peninsula-some being present in and some absent from western France-among which the strawberry tree (Arbutus unedo) is perhaps the best known.

Several speakers-for example Miss Chandler, Prof. Boswell, Dr. W. B. Wright, Mr. Butcher and Dr. Hamshaw Thomas-emphasised from different points of view the extreme complexity of the changes and the wide fluctuations of climate and other conditions which must have occurred during the Pleistocene. Other speakers, again, directed attention to factors which are probably of great importance but are often ignored-Dr. Thomas to the importance of precipitation and accompanying humidity of the air, in addition to temperature; Dr. A. S. Watt to soil development, different soil phases limiting the spread of particular species and favouring that of others; Dr. W. B. Turrill to 'ecotypes' within an aggregate species which may all have a general superficial resemblance but in reality differ greatly, both in genetic constitution and in ecological requirements.

Dr. H. Godwin gave a lucid account of the application of the modern technique of pollen analysis to the interpretation of the post-glacial history of the British flora, showing that the succession of forest types in Britain agrees very well in a general way with that recorded from the Continent. It is difficult to judge the time of the first appearance of the dominant trees, but the order in which they spread and attained dominance can be determined with some certainty. The earliest post-glacial forest phase (Boreal) shows dominance of birch and pine and the entry of elm, oak and lime. Later came the alder, and the next climatic period (Atlantic) saw mixed oak-forest and alder dominant. It is now certain also that beech, on the native place of which doubts have been cast, was present in pre-Roman (probably Iron Age) times; and hornbeam has a similar status. Both these records agree well with the late post-glacial spread of the two trees on the Continent. There is also evidence of a second pine forest maximum between the early Bronze Age and the Roman period, and this perhaps corresponds with the Sub-boreal pine maxima in Ireland, Scandinavia and other parts of Great Britain. Not very much is certainly known of the pollen of British interglacial beds, but the presence of spruce-now extinct-has been established, so that extermination of some species at least during the later glaciations appears to be demonstrated.

A. G. Tansley.

\title{
The Alkali Industry
}

$\mathrm{I}^{\mathrm{N}}$ the Hurter Memorial Lecture to the Society of Chemical Industry (Chemistry and Industry, 54,121 ; 1935), Dr. J. T. Conroy gave a very interesting review of the development of the manufacture of sulphuric acid, alkali, chlorine and allied products since about 1890. This period has seen the disappearance of the Leblanc process and its replacement by electrolytic processes, the Castner and Hargreaves processes developed in Great Britain having features embodied in most successful modern cells except those of the gravity type. The possibility of operating these processes was almost entirely dependent on power production. The original rocking mercury cell has given way to a trough type with many times the capacity of the original unit, and the use of Acheson artificial graphite for the anodes was a material improvement. The high degree of purity of the caustic soda produced by the Castner cell, fitting it for the electrolytic production of metallis sodium, was very helpful to its development. The sodium is the starting material for the manufacture of cyanide. For the last fifteen years the chlorine produced in Great Britain has been electrolytic in origin.

In the ammonia-soda process, improvement in plant and operation has been effected, and processes for the production of sal ammoniac and calcium chloride from appropriate tower and still liquors have been developed.

Although the Leblanc cycle has been superseded, some intermediate products are still important. Sulphuric acid is made by the chamber process, in the operation of which some mechanical improvements have been effected, and on the chemical side the use of nitre has been replaced by ammonia oxidation. Concentration of acid in platinum pans has given way to other types of apparatus and finally to the contact process. It is only with large installations and a demand for high strength acid, such as is necessary in the dyestuffs industry, that the contact process is economical. The use of sulphur has replaced that of pyrites to a large extent since the exploitation of the American deposits by the Frasch process.

The manufacture of saltcake (sodium sulphate) has declined considerably, partly because saltcake is now largely displaced by ammonia soda ash in glass manufacture and partly because the export market demands have been largely met by the recovery of sodium sulphate from residual 
liquors from the recovery of natural potash at Kaiseroda and Borbach, from which on refrigeration Glauber's salt is obtained, yielding saltcake of high purity on suitable heat treatment.

The Weldon chlorine process had been displaced by the Deacon process as improved by Hasenclever. The production of $\mathbf{l}$ ton of bleaching powder by the Weldon process required $50 \mathrm{cwt}$. of salt; in the Deacon process appreciably less than $20 \mathrm{cwt}$. was used. Kynaston found that the undecomposed hydrochloric acid washed from the chlorine was almost free from arsenic and contained but little $\mathrm{SO}_{3}$, so that this acid could be sold and the costly Hasenclever process, degassing the condensed acid for return to the decomposer, could be avoided. A revolution in the manufacture of hydrochloric acid came with the production of synthetic acid from the hydrogen and chlorine gases from the electrolytic cell, and a high proportion of the acid is now produced synthetically.

In the manufacture of bleaching powder, the use of the Hasenclever plant, in which mechanically hydrated lime is pushed through horizontal superimposed cylinders in counter current to the ascending chlorine, has been modified by the omission of the propelling blades and the use of a single enlarged rotating cylinder for the smaller units (Moore and Rudge). The chlorine from the electrolytic cells is diluted with air before use, and by suitable regulation of the process and control of temperature in particular zones of the cylinder by water cooling, a high strength bleaching powder possessed of stability in hot climates can be produced. Calcium hypochlorite containing more than 70 per cent available chlorine, and sodium hypochlorite solutions containing up to 15 per cent available chlorine are produced for water purification, sanitation, laundry work and other purposes.

The production and sale of liquid chlorine for water purification and the preparation of intermediates in the dyestuffs industry is another notable achievement. Chlorate production is now also electrolytic and is carried out in countries such as Sweden and Canada where cheap waterpower is available.

In the caustic soda industry, the carbonate from the ammonia soda process is causticised with lime, the calcium carbonate in granular form being removed by rotary filters and used as agricultural lime, in 'stone dusting' in coal mines and, when carefully dried and air-separated, in other industries. Regeneration of lime from the lime mud has more recently been accomplished. The caustic soda liquor is concentrated in multiple effect evaporators and further in steam-heated units, the product being of high strength, 70 per cent $\mathrm{Na}_{2} \mathrm{O}$ being normally attained, whilst with the mercury electrolytic cell a product approximating to 100 per cent $\mathrm{NaOH}$ is obtainable. New forms of caustic soda known as flake, petal and powder, are made by breaking down thin sheet; they are easy to handle and much purer than the old stick form.

Purity of the modern products is due partly to the basic change of process, for example, contact process for sulphuric acid and synthesis of hydrochloric acid, and partly by the possibility of installing purification plant owing to economy resulting from greater output per unit of plant. Fuel economy has been largely effected by the development of the tubular boiler and the steam turbine. The use of control instruments and better working conditions on the plant, as well as the introduction of metals and alloys capable of resisting corrosive liquids and gases, have all played a part in the improvement of the industry. Dr. Conroy emphasised that the continuous high efficiency now ruling can only be maintained and ensured by continuous scientific control.

\section{Obituary}

\section{Prof. E. Paternò}

$\mathrm{T}$ HE death of Emanuele Paternò removes a leading Italian chemist and a genial collaborator from the international councils of chemistry, where he regularly represented his country. Prof. Paternò passed away on January 18 in his native city of Palermo, where he was born on December 12, 1847. His father had to leave Sicily soon after his birth, having taken an active part in the revolt of 1848 , and Emanuele spent his early years in exile, in Alexandria.

Having graduated in physics and chemistry, Paternò returned to Palermo, replacing in 1872 the famous chemist Cannizzaro, who had just left for Rome. In 1893 he was called to the chair of applied chemistry in Rome, and on the death of Cannizzaro he became director of the Chemical Institute.

Paternò's scientific contributions over nearly half a century are numerous and varied. He began his scientific career with the discovery of dichloraldehyde, and made a special study of the halogen isomers of ethane, the synthesis of fluorbenzene, fluortoluene, etc. Passing on to physical methods, he made numerous cryoscopic studies in connexion with the determination of molecular weights, and later in life investigated colloidal phenomena and the influence of light upon chemical reactions.

Paterno was the first to point out, in 1889 , the emulsion-like nature of colloidal solutions, and to note that a substance may be colloidally dispersed 